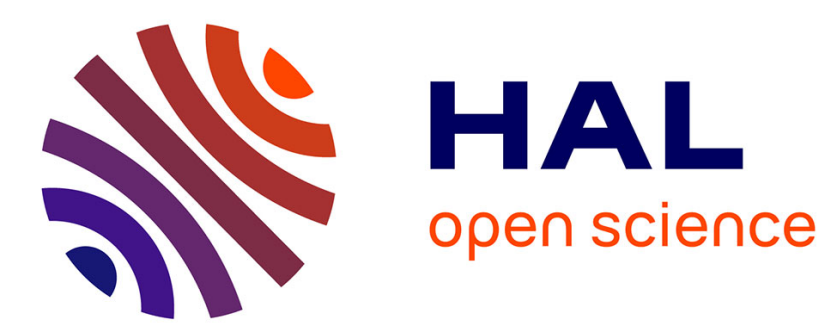

\title{
Effects of shrub and canopy cover on the relative growth rate of Pinus pinaster Ait. seedlings of different sizes
} Rodríguez-García, Ordóñez, Bravo

\section{To cite this version:}

Rodríguez-García, Ordóñez, Bravo. Effects of shrub and canopy cover on the relative growth rate of Pinus pinaster Ait. seedlings of different sizes. Annals of Forest Science, 2011, 68 (2), pp.337-346. 10.1007/s13595-011-0039-5 . hal-00930774

\section{HAL Id: hal-00930774 https://hal.science/hal-00930774}

Submitted on 1 Jan 2011

HAL is a multi-disciplinary open access archive for the deposit and dissemination of scientific research documents, whether they are published or not. The documents may come from teaching and research institutions in France or abroad, or from public or private research centers.
L'archive ouverte pluridisciplinaire HAL, est destinée au dépôt et à la diffusion de documents scientifiques de niveau recherche, publiés ou non, émanant des établissements d'enseignement et de recherche français ou étrangers, des laboratoires publics ou privés. 


\title{
Effects of shrub and canopy cover on the relative growth rate of Pinus pinaster Ait. seedlings of different sizes
}

\author{
Encarna Rodríguez-García • Cristóbal Ordóñez • \\ Felipe Bravo
}

Received: 7 April 2010 /Accepted: 4 September 2010 / Published online: 3 March 2011

(C) INRA and Springer Science+Business Media B.V. 2011

\begin{abstract}
- Introduction Shrubs are recognized as important tree regeneration niches. In this study, we experimentally analysed the effects of shrub presence, canopy cover (closed cover and open cover-gaps), and seedling size on Pinus pinaster growth.

- Objective We expected that (1) seedling-shrub interaction would depend on seedling size and would shift from positive to negative with increasing size; (2) overstorey canopy would affect seedling-shrub interaction, with stronger and positive interactions in gaps, and (3) microsite factors would be affected by vegetation. Social status and plant size appeared to determine the post-shrub-treatment growth response.

- Results The effect of shrub on seedling growth varied with the canopy cover. Under closed canopy, there was a shift from a positive net effect on smaller seedlings to a negative net effect on mid-size seedlings, and then back to a positive net effect on larger seedling response. Under open canopy, a negative net effect was observed, with no change in the sign of the interaction as seedling size increased. Microenvironmental conditions varied in relation to overstorey and understorey vegetation, while soil conditions
\end{abstract}

Handling Editor: David E. Hibbs

E. Rodríguez-García $(\bowtie) \cdot$ C. Ordóñez $\cdot$ F. Bravo

Departamento de Producción Vegetal y Recursos Forestales. E. T.

S. de Ingenierías Agrarias, Universidad de Valladolid,

Avenida Madrid, 44,

34004 Palencia, Spain

e-mail: ergarcia@pvs.uva.es

E. Rodríguez-García $\cdot$ C. Ordóñez $\cdot$ F. Bravo

Sustainable Forest Management Research Institute UVA-INIA,

Avenida Madrid, 44,

34004 Palencia, Spain varied in relation to overstorey. The seedling-shrub interaction had both positive and negative net effects, which could help define the natural regeneration dynamic of $P$. pinaster.

Keywords Mediterranean maritime pine.

Natural regeneration · Plant-plant interactions .

Overstorey structure

\section{Introduction}

The study of plant interactions may help us to understand the population dynamics that drive successional changes in forest communities and to design sound vegetation management methods (Letourneau et al. 2004). The early establishment phase in the life cycle of trees is influenced by the presence and abundance of understorey. Many studies have provided evidence that shrubs are important regeneration niches for tree species (Callaway 1995; Callaway and Walker 1997; Gómez-Aparicio et al. 2005). Plant-plant interactions vary from positive relationships such as facilitation to negative relationships such as competition and allelopathy (Callaway and Walker 1997). The terms facilitation and competition refer to the net effect of changes in the environment of a plant due to the presence of other plants (Holmgren et al. 1997). The balance appears to vary according to the life stages and physiologies of the interacting species (Callaway and Walker 1997; Holmgren et al. 1997), site factor heterogeneity (Gómez-Aparicio et al. 2005; Hartgerink and Bazzaz 1984; Kitzberger et al. 2000; Tielbörger and Kadmon 2000), and the intensity of abiotic stress experienced by the interacting species (Bertness and Callaway 1994). Facilitation and the mechanisms involved in it have been amply 
described (Callaway 1995). Improvement of plant-water relations in shade is commonly observed, but facilitative effects could result from other mechanisms such as changes in nutrient availability or a reduction in herbivory (Holmgren et al. 1997).

Plant size is a function of life stage, thus the size of beneficiary species may have important effects on plantplant interactions. Several studies have shown that facilitation can shift to competition as the beneficiary matures (Callaway and Walker 1997; Kellman and Kading 1992; Kitzberger et al. 2000; Pugnaire et al. 1996). As a plant grows, it requires more space to accommodate itself, so when the beneficiary overtops the benefactor, stem and crown interference may occur in the form of competition for light and space, while root interference may occur as competition for minerals and water (Kramer and Kozlowski 1979). Grime (1979) hypothesized that plant habitat competition intensifies along an increasing gradient of primary productivity. Bertness and Callaway (1994), hypothesized that the importance of competition would increase when abiotic stress and consumer pressure were relatively low, but competition between plants can be expected in highly stress-tolerant species (Grime 1979).

Our understanding of the role of shrubs on the natural regeneration of maritime pine (Pinus pinaster Ait.) is limited. An evaluation of shrub and overstorey effects on the natural regeneration of this species could help to identify possible underlying processes or determine appropriate management strategies for natural establishment, such as site preparation, control of competing vegetation and tree harvest selection to create canopy openings. Few studies have analysed overstorey structure and shrub effects on natural regeneration and the relative growth rate (RGR) of seedlings (Beckage et al. 2008; Pecot et al. 2007). Most "nurse shrub" studies have only considered the effect of shrubs on seedling performance in open areas, but not the effect of overstorey canopy on the relationship. In this study, we experimentally analysed the effects of shrub presence, canopy cover, and seedling size on $P$. pinaster growth. We expected that (1) the strength and the sign of the seedling-shrub interaction would depend on the seedling size, and the strength would increase and the sign would shift from positive to negative with increasing seedling size; (2) seedling-shrub interaction would vary depending on the overstorey canopy, with stronger and positive interactions at more stressful sites (for example, open canopy with high-light levels that could produce photoinhibition and thermal fluctuations). Conversely, a negative interaction would be expected under closed canopy conditions, with greater availability of resources (soil water and air moisture); and (3) microclimatic and soil conditions would be affected by overstorey and understorey vegetation, which could affect the outcome of the interaction.

\section{Material and methods}

\subsection{Study area}

The study was conducted in a mature $P$. pinaster forest located at 1,050 m.a.s.l., in Las Navas del Marqués, Ávila $\left(40^{\circ} 33^{\prime} \mathrm{N}\right.$ and $\left.4^{\circ} 20^{\prime} \mathrm{W}\right)$, in the Central Mountain System of peninsular Spain. The climate in the study area is typically Mediterranean, with rainfall mainly distributed in autumn and spring, average annual precipitation of $738 \mathrm{~mm}$, and an average annual temperature of $10^{\circ} \mathrm{C}$. Summer precipitation is usually scarce, with minimum values in July and August. The soil is siliceous and classified as an Entisol. The understorey vegetation is mainly composed of the shrub Cistus ladanifer L. The stand ( $\sim 25$ ha) was partially harvested in 1996 and 1997 using a shelterwood method that varied overstorey retention densities and created canopy gaps. The stand was fenced to keep out livestock. The experiment was started in March, 2008, and the final measurements were made in early January, 2009.

\subsection{Experimental design}

The study was carried out in a set of circular plots, which were stratified based on the canopy cover and, measured with a spherical densiometer. Two types of canopy cover were established: open canopy, (gaps) with an average density of 56.59 trees $\mathrm{ha}^{-1}$ and closed canopy, with an average of 146.19 trees $\mathrm{ha}^{-1}$. Three circular plots, each with a $15 \mathrm{~m}$ radius, were established for each type of canopy cover. Different variables were measured within these plots to classify the overstorey structure (Table 1), and shrubs were removed to carry out the main experiment. To estimate post-harvest regeneration and the amount of shrub present (Table 1) as well as to analyse the spatial association between those seedlings and shrubs, four circular subplots, with radii of $2.5 \mathrm{~m}$ were established within each $15 \mathrm{~m}$ plot, at each of the four cardinal points, and $7.5 \mathrm{~m}$ from the plot centre (Fig. 1). We used the subplots to measure overstorey light, and soil conditions in three shrub-free and three shrubshaded sampling points. These were chosen at random and representative of growth conditions under both types of canopy cover. Measurements taken in one subplot per canopy cover type were used to classify microclimate conditions in shrub-free and shrub-shaded sampling points. 
Table 1 Main characteristics of overstorey and understorey structure, and average height and basal diameter of the seedlings used in the shrub-removal experiment, in plots under open canopy and closed canopy cover of Pinus pinaster (mean $\pm \mathrm{SE})$

${ }^{a}$ Measured with a densiometer

\begin{tabular}{llrr}
\hline Variables & Description and units & Closed canopy & Open canopy \\
\hline Overstorey & & & \\
CC-h & & & \\
D & Canopy cover $(\%)$ & $32.14 \pm 0.55$ & $5.10 \pm 0.57$ \\
BA & Density $\left(\mathrm{N} \mathrm{ha}^{-1}\right)$ & $146.19 \pm 15.37$ & $56.59 \pm 5.32$ \\
$H_{0}$ & Residual basal area $\left(\mathrm{m}^{2} \mathrm{ha}^{-1}\right)$ & $16.66 \pm 0.79$ & $7.50 \pm 0.69$ \\
Dbh & Assman's dominant height $(\mathrm{m})$ & $18.16 \pm 0.07$ & $14.95 \pm 0.48$ \\
Understorey & Diameter at breast height $(\mathrm{cm})$ & $32.14 \pm 0.55$ & $35.92 \pm 1.17$ \\
ShC & & & \\
ShH & Shrub cover $(\%)$ & $50.54 \pm 5.21$ & $63.94 \pm 1.63$ \\
Treated seedlings & Shrub height $(\mathrm{cm})$ & $135.73 \pm 6.88$ & $128.75 \pm 4.26$ \\
$h_{0}$ & & & \\
Size 1 $(\mathrm{cm})$ & Initial height $(\mathrm{cm})$ & & $47.62 \pm 5.08$ \\
Size 2 $(\mathrm{cm})$ & & $44.28 \pm 4.70$ & $62.48 \pm 5.60$ \\
Size 3 $(\mathrm{cm})$ & & $72.22 \pm 4.70$ & $136.98 \pm 6.15$ \\
$d_{0}$ & & $122.68 \pm 5.48$ & \\
Size 1 $(\mathrm{cm})$ & Initial basal diameter $(\mathrm{cm})$ & & $1.03 \pm 0.14$ \\
Size 2 $(\mathrm{cm})$ & & $0.93 \pm 0.13$ & $1.49 \pm 0.15$ \\
Size 3 $(\mathrm{cm})$ & & $1.54 \pm 0.13$ & $3.24 \pm 0.16$ \\
\hline
\end{tabular}

\subsection{Spatial association between regeneration and shrubs}

Spatial association between established seedlings and shrubs was analysed within the four subplots according to the methodology proposed by Kitzberger et al. (2000). All seedlings were counted and numbered with a metal label. The total density of seedlings per ha ${ }^{-1}$ was calculated for each plot as the average of all subplots. Shrub height and shrub coverage percentage were measured. Shrub coverage was measured visually to the nearest $5 \%$ within the subplots. Shrub height and coverage percentage for each plot were calculated as the average of all subplots. Seedling
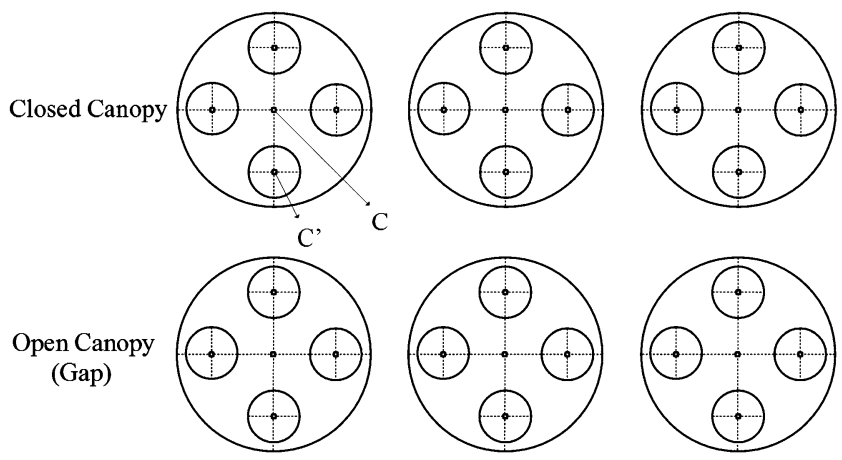

$\mathrm{C}=$ Centre of the plots with radius $15 \mathrm{~m}$

$\mathrm{C}^{\prime}=$ Centre of the subplots with radius $2.5 \mathrm{~m}$

$C--C^{\prime}=7.5 \mathrm{~m}$

Fig. 1 Layout of the plots and experimental design height and distance to the geometrical centre of the nearest shrub were measured and seedlings were classified into two categories of shrub proximity: as either inside $(0-30 \mathrm{~cm})$ or outside $(>30 \mathrm{~cm})$ of the shrub canopy. The spatial position of all shrubs within the subplots was determined by their distance and angle from the plot centre, assessed with the aid of a Vertex and a compass suspended from a tripod. For each subplot, a number of random points (equal to the number of seedlings measured within the plot) was established in the laboratory by generating independent " $x$ " and " $y$ " coordinates with uniform distribution, and then distances were calculated from the points to the nearest shrub. Using the distance of all seedlings to the nearest shrub and the distance of all calculated random points to the nearest shrub within each subplot, the null hypothesis (i.e., that the distribution of $P$. pinaster seedlings was independent from distance from shrubs) was then tested with a Chisquare test, using the SPSS 15.0 statistical package.

\subsection{Effect of shrubs on $P$. pinaster seedling growth} and the role of overstorey

In order to test the effects of shrubs and overstorey on the growth of $P$. pinaster seedlings, a shrub-removal experiment was carried out within the $15 \mathrm{~m}$ plots. Three seedlingshrub environments per type of canopy were considered: (1) seedlings growing in areas free of shrubs, presenting no shrub within a radius of $\leq 1 \mathrm{~m}$ (overall further) around the 
seedling (Shr-F); (2) seedlings growing in the presence of shrubs (Shr-P); and (3) seedlings growing in areas where shrubs had been removed (Shr-R). Seedlings considered for treatments Shr-P and Shr-R were completely surrounded by shrub. Note that due to the shrub height (Table 1), no-shrub treatments (Shr-F and Shr-R) should be thought of as seedlings growing in the absence of shrubs, with a low but likely shelter effect. Three categories were established to test the effect of seedling size relative to the height of surrounding shrubs: size 1 or small (seedling height, $\leq 1 / 3$ of shrub height), size 2 or mid-size (seedling height, $>1 / 3$ but $<2 / 3$ of shrub height), and size 3 or large (seedling height, $\geq 2 / 3$ of the shrub height). Seedlings selected by size were homogeneous in age. Three seedlings per size category were used in each shrub treatment $(n=9)$, for a total of 27 seedlings per plot. The seedlings selected were adequately spaced to prevent intraspecific competition from other seedlings in the same location. In the removal treatment (Shr-R), shrubs were removed with secateurs, cutting the aerial part to ground level in a $1 \mathrm{~m}$ circular area around the seedlings. In all cases, the shrub removed had covered the entire $1 \mathrm{~m}$ radius around the seedling, and was homogeneous in cover and height (Table 1) for all treatments and types of canopy cover. The shrubs were removed early in the growing season (March 2008).

Once the seedlings had been selected, the height and seedling basal diameter at ground level were measured two times, in March, 2008 and January, 2009. The RGR in stem volume $\left(\mathrm{cm}^{3}\right)$ was then calculated for each seedling as:

$\mathrm{RGR}=\frac{V_{1}-V_{0}}{V_{0}}$

where RGR represents the fraction of stem volume increment observed in one growth period, calculated as:

$V_{i}=\frac{1}{3} \pi d_{i}^{2} h_{i}$

where $V_{i}$ is the plant volume with $i=0$ being the volume in March, 2008 and $i=1$ being the volume in January, 2009; $d$ is the basal diameter of the seedling (the average in centimetres between two perpendicular measurements at floor level); and $h$ is the height of the seedling (centimetres).

The differences in relative growth rate were examined by a general linear model (GLM) with a split-plot design, using seedling size, shrub treatment and canopy as factors. Since the canopy cover factor was associated with the plot, but the other two factors (shrub presence and seedling size) were split within the plot, the variation within plots was examined and the error term associated with the canopy in the GLM was recalculated (plot nested in canopy cover treatment). The variables analysed (RGR, $V_{0}$, and $V_{1}$ ) were subjected to a natural logarithm transformation. Fisher's LSD test was used for all pairwise comparisons of least- squares means to detect differences between treatments. Spearman's rank-order correlations were also used to explore the relationship between the natural logarithm of the initial stem volume $\left(\ln V_{0}\right)$ and relative growth rate volume (lnRGR) of the seedlings, and the relationship between these variables and established seedling density, shrub coverage, and environmental variables related to overstorey light and soil characteristics. The analyses were carried out with the Statistica 6.0 software package.

\subsection{Environmental measurements}

Light environment above the seedlings and understorey was classified by taking five hemispherical photographs per plot (one per subplot plus one in the centre of the $15 \mathrm{~m}$ plot) under both types of canopy cover. The images were analysed with Gap Light Analyser software (GLA 2.0). The light-related parameters obtained were canopy openness (CO), leaf area index (LAI) $0-75^{\circ}$ from the zenith and other attributes of canopy structure and transmitted gap light such as $\%$ trans direct (Trans-Dir); $\%$ trans diffuse (Trans-Dif); and \% trans total (Trans-Tot). These describe the transmittance or amount of transmitted direct, diffuse and total radiation incident on a horizontal surface when light is blocked by the surrounding topography and overlying forest canopy (Frazer et al. 1999). Photographs were taken at dawn in March, 2008 with an Fc-E9 fisheye adapter lens mounted on a Nikon Coolpix 4500 camera. The camera was placed on a level tripod at a height of $1.30 \mathrm{~m}$ from the ground. Image pixel positions were transformed to angular coordinates from a manual threshold defined for each photograph. The values obtained for the variables were averaged per plot, and differences in light environment between the two types of canopy cover were tested by one-way ANOVA. The analyses were carried out with the Statistica 6.0 software package.

Twenty-four soil samples were taken from the upper $20 \mathrm{~cm}$ of each plot in July, 2008 (six per subplot: three from shrub-shaded points and three from shrub-free points, for a total of 144) and transported to the laboratory for classification. The volumetric soil water content (VWC \%) was measured gravimetrically. Nutrient contents and percentage of soil particles by size were calculated by standard procedures. The percentage of sand, silt and clay were also determined. Nitrogen content was determined by Kjedahl method, organic matter $(\mathrm{OM})$ by the carbon method and phosphorus by the Olsen method. Concentrations of potassium, calcium $(\mathrm{Ca})$, magnesium, and sodium were determined after extraction with $1 \mathrm{~N}$ ammonium acetate. Soil $\mathrm{pH}$ (suspension 1: 2.5) and electrical conductivity values were also obtained. The values of the parameters were averaged per plot, and differences between microhabitats (shrub/no shrub) and 
between types of canopy cover were tested by GLM with a split-plot design (plot nested in canopy treatment).

Microenvironmental conditions were recorded on six summer days, July 24 to 31,2008 at three shrub-shaded sampling points (relative to the geometrical centre of the shrub), and three shrub-free sampling points, in one randomly selected subplot per canopy cover type (total of two subplots). Sampling points were chosen at random and were representative of growth conditions. Air temperature and relative air humidity were measured and recorded with HOBO sensors (HOBO Pro v2 RH/Temp; Onset computers, Pocasset, MA, USA) every $30 \mathrm{~min}$ at $10-\mathrm{cm}$ intervals on the forest floor. Soil temperature was recorded every $15 \mathrm{~min}$ at a depth of $3 \mathrm{~cm}$ with probes connected to HOBO data loggers protected by a PVC hood (Onset computers, Pocasset, MA, USA). The measurements recorded over the 6-day period were averaged, and differences between microhabitats and between types of canopy cover were tested by two-way ANOVA. All of the above analyses were carried out with the Statistica 6.0 software package.

2.6 Net balance of seedling-shrub interaction in relation to overstorey

A facilitation index was used to summarise the differences in seedling sizes, types of canopy cover and the strength and sign of the seedling-shrub interaction. We modified the relative neighbour effect index (RNE) of Callaway et al. (2002), so that

$\mathrm{RNE}=\frac{X_{\mathrm{c}}-X_{\mathrm{t}}}{x}$

where $X$ is an estimate of plant performance (RGR) in the presence (c) or absence (t) of neighbours, and $x$ is the highest value of the pair $X_{\mathrm{t}}, X_{\mathrm{c}}$. The modified index varies from -1 to 1 , with positive values indicating facilitation and negative values indicating competition. We calculated the estimated RNE for two situations: (1) as the difference between seedling RGR in areas where shrubs were present (Shr-P) and seedling RGR where shrub had been removed (Shr-R), and (2) as the difference between seedling RGR in areas where shrubs were present and the RGR of seedlings growing in the absence of shrubs (Shr-F).

\section{Results}

\subsection{Spatial association between seedlings and shrubs}

P. pinaster seedlings established after stand harvesting were more frequent (Fig. 2) under shrub than would be expected by chance in open canopy plots $\left(\chi^{2}=10.39 ; p=0.002\right)$. Within closed canopy plots, the relationship between

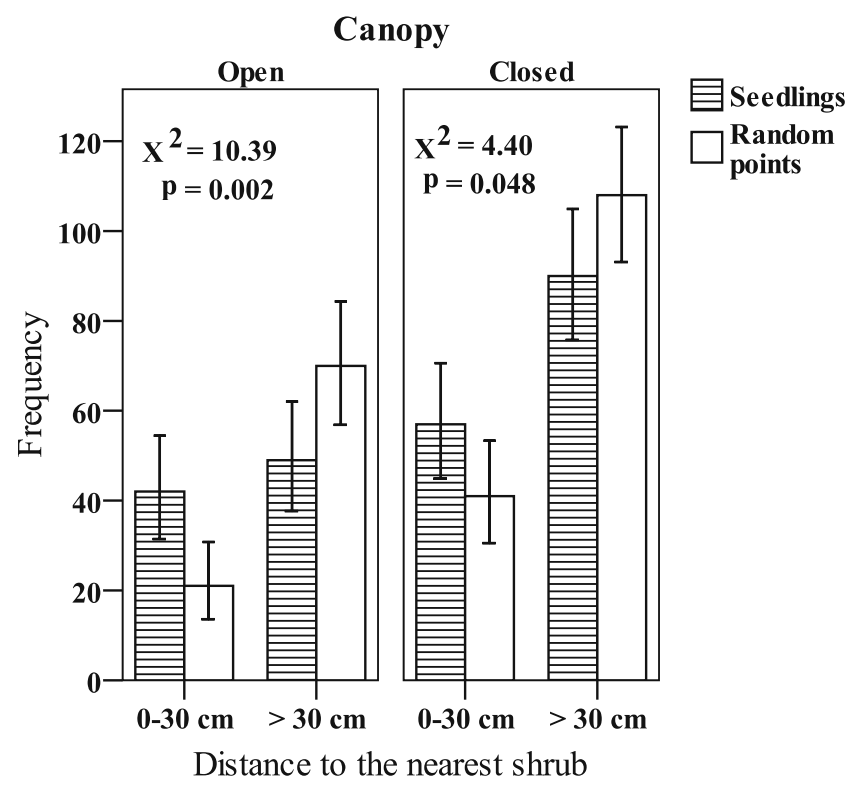

Fig. 2 Frequency distribution and Chi-square test of distances between Pinus pinaster seedlings and nearest shrub, and distances between random points and nearest shrub, under open canopy cover and closed canopy cover. Vertical bars denote 0.95 confidence interval

seedling establishment distribution and the distance to shrubs was barely significant $\left(\chi^{2}=4.40 ; p=0.048\right)$.

3.2 Effects of seedling size and overstorey on the response to shrub removal

The effect of shrub treatment on the relative growth of seedlings was low and varied significantly $(F=121.3 ; p<$ 0.01 ) with the type of canopy cover (Table 2 ). The RGR varied significantly between seedling size classes $(F=$ $4.9 ; p<0.001)$, and was higher for taller seedlings under both types of canopy cover (Fig. 3). The effect of shrub removal on seedling RGR for size 1 was not significant and did not differ between types of canopy cover (Fig. 3). Seedling RGR for size 2 increased significantly with shrub removal under open canopy, and the RGR of size 3 seedlings was not affected by shrub removal. However, the relative growth rate of size 3 seedlings in the absence of shrubs (Shr-F) was significantly higher than those growing in the presence of shrubs (Shr-P). Size 3 seedling RGR in the presence of shrubs under closed canopy was not significantly different from that of size 3 seedlings under open canopy in areas free of shrubs.

Under closed canopy, initial seedling stem volume $\left(\ln V_{0}\right)$ was positively related to shrub cover $\left(r_{s}=0.32 ; p=0.006\right)$, canopy openness $\left(r_{s}=0.39 ; p=0.001\right)$, direct transmittance $\left(r_{s}=0.31 ; p=0.006\right)$, and total transmittance $\left(r_{s}=0.38 ; p=\right.$ $0.001)$; but the relationship with diffuse transmittance was strongest $\left(r_{s}=0.40 ; p<0.001\right)$. This variable was also 
Table 2 Summary of the general linear model parameters for the analysis of the effect of canopy cover (canopy), shrub treatment (shrub), and seedlings size (size) on the natural logarithm of relative growth rate (lnRGR) of Pinus pinaster seedlings

\begin{tabular}{lccc}
\hline Model $R_{\text {adj }}{ }^{2}(0.66)$ & SS & $d f$ & $p$ Value \\
\hline Intercept & $2,685.010$ & 1 & 0.000 \\
Canopy & 1.68 & 1 & 0.479 \\
Whole plot error & 11.05 & 4 & \\
Shrub & 3.30 & 2 & 0.167 \\
Size & 220.52 & 2 & 0.000 \\
Shrub $\times$ size & 6.66 & 4 & 0.127 \\
Canopy $\times$ shrub & 8.93 & 2 & 0.009 \\
Canopy $\times$ size & 3.59 & 2 & 0.143 \\
Canopy $\times$ shrub $\times$ size & 3.37 & 4 & 0.452 \\
Split-plot error & 107.15 & 118 & \\
\hline
\end{tabular}

found to be negatively related to overstorey density $\left(r_{s}=-0.35 ; p=0.002\right)$, LAI $\left(r_{s}=-0.39 ; p=0.006\right)$, soil organic matter $\left(r_{s}=-0.38 ; p=0.01\right)$, and volumetric water content in the soil $\left(r_{s}=-0.30 ; p<0.01\right)$. Relative growth rate $(\operatorname{lnRGR})$ was related to $\ln V_{0}\left(r_{s}=0.96 ; p=0.001\right)$, diffuse transmittance $\left(r_{s}=0.33 ; p=0.013\right)$, total transmittance $\left(r_{s}=0.32 ; p=0.005\right)$, canopy openness $\left(r_{s}=0.30 ; p=\right.$ $0.009)$, and direct transmittance $\left(r_{s}=0.29 ; p=0.013\right)$; but it was negatively related to LAI $\left(r_{s}=-0.30 ; p=0.009\right)$ and overstorey density $\left(r_{s}=0.25 ; p=0.033\right)$. Under open canopy cover, no significant relationships were found between these parameters and the variables.
3.3 Environmental variation in relation to understorey presence and overstorey structure

Light environment varied significantly between the two types of canopy cover. The LAI was two times higher, while direct and diffuse transmittances were lower in closed canopy plots than in open canopy plots (Table 3). Differences in microclimate and soil properties between closed canopy and open canopy were observed (Table 3). The average daily soil temperature and the soil temperature at noon were significantly lower under closed canopy than the average noon value of $39^{\circ} \mathrm{C}$ in shrub-free microsites under open canopy. The nitrogen and calcium soil content and air temperature were significantly lower under closed canopy, while relative air humidity, soil volumetric water content and phosphorous levels were significantly higher. Under both canopy types, shrub-shaded microsites had higher relative air humidity and lower soil temperature at noon when compared with shrub-free sites.

\subsection{Net effect of shrubs-over-seedling performance}

Simultaneous positive and negative interactions were observed within the study system (Table 4). The RNE index showed that under open canopy, the intensity of the interaction increased with seedling size, especially when comparing seedlings growing in the presence or absence of shrubs (Shr-P/Shr-F), but there was no change in the interaction sign from small seedlings to larger seedlings, which was negative for all plant sizes and more negative for mid-size seedlings (Shr-P/Shr-R). Under closed canopy the strength of the interaction increased with seedling size when
Fig. 3 Natural logarithm of the average relative growth rate (RGR) of established seedlings of sizes 1, 2, and 3, of Pinus pinaster under two types of canopy cover, where Shr-F corresponds to seedlings growing free of shrub, Shr-P corresponds to seedlings growing under shrub presence and Shr-R corresponds to seedlings with shrub removed. LnRGR refers to stem volume in $\mathrm{cm}^{3}$. Different letters show significant differences $(p<0.05)$ between treatments. Vertical bars denote 0.95 confidence interval
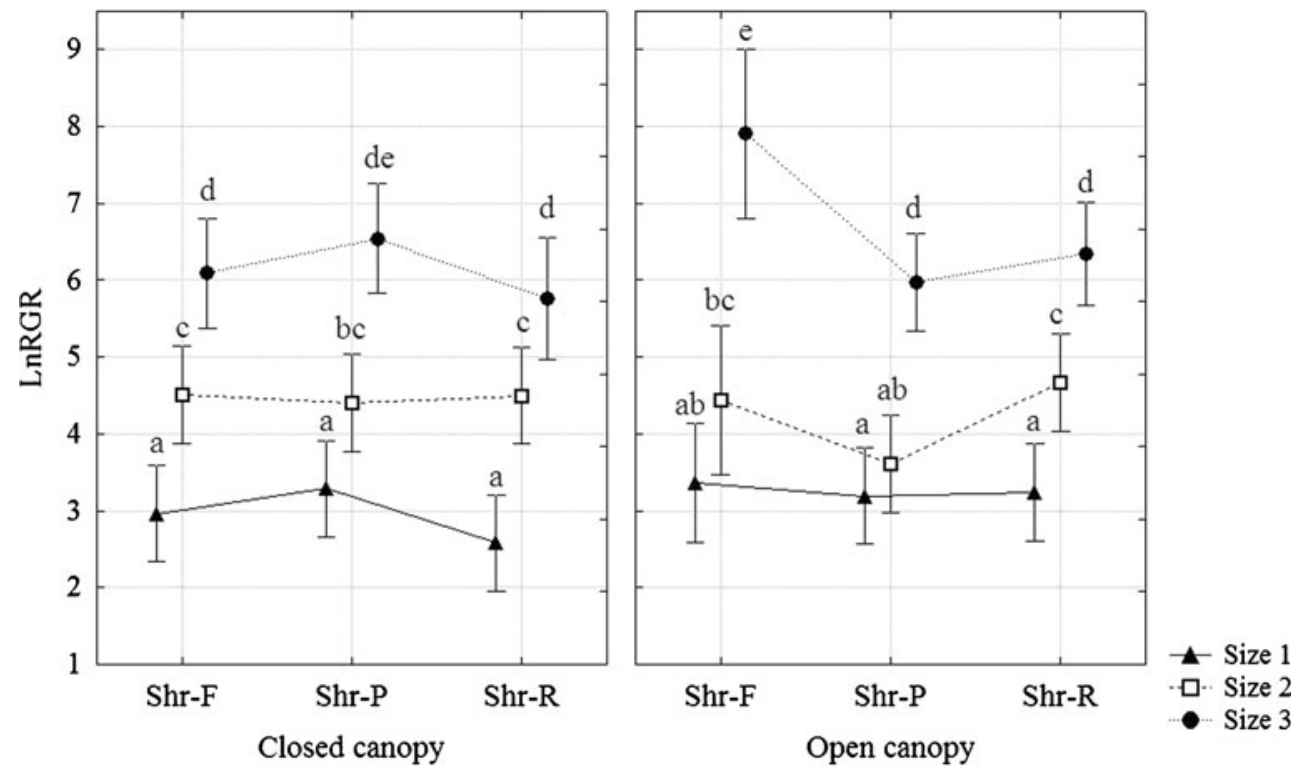
Table 3 Values of the light conditions, microclimatic conditions and soil properties measured in July 2008 under shrub-shaded and shrub-free sampling points (mean \pm SE)

\begin{tabular}{|c|c|c|c|c|}
\hline \multirow[t]{2}{*}{ Variable } & \multicolumn{2}{|l|}{ Closed canopy } & \multicolumn{2}{|l|}{ Open canopy } \\
\hline & Shrub-free & Shrub-shaded & Shrub-free & Shrub-shaded \\
\hline \multicolumn{5}{|l|}{ Light } \\
\hline $\mathrm{CO}$ & $47.8 \pm 5.0 \mathrm{a}$ & & $61.6 \pm 2.4 b$ & \\
\hline $\mathrm{CC}$ & 52.2 & & 38.4 & \\
\hline LAI & $0.6 \pm 0.1 \mathrm{a}$ & & $0.3 \pm 0.04 \mathrm{~b}$ & \\
\hline (\%)Trans-Dir & $59.4 \pm 5.3 \mathrm{a}$ & & $76.3 \pm 7.3 b$ & \\
\hline (\%)Trans-Dif & $57.7 \pm 5.3 \mathrm{a}$ & & $76.7 \pm 3.1 b$ & \\
\hline (\%)Trans-Tot & $58.5 \pm 4.4 \mathrm{a}$ & & $76.5 \pm 4.6 b$ & \\
\hline \multicolumn{5}{|l|}{ Soil } \\
\hline VWC & $2.55 \pm 0.40 \mathrm{a}$ & $2.86 \pm 0.23 \mathrm{a}$ & $1.93 \pm 0.16 b$ & $2.19 \pm 0.17 b$ \\
\hline $\mathrm{pH}$ & $5.94 \pm 0.04 \mathrm{a}$ & $5.84 \pm 0.03 \mathrm{a}$ & $5.86 \pm 0.10 \mathrm{a}$ & $5.84 \pm 0.08 \mathrm{a}$ \\
\hline $\mathrm{EC}$ & $0.03 \pm 0.00 \mathrm{a}$ & $0.04 \pm 0.00 \mathrm{a}$ & $0.07 \pm 0.03 \mathrm{a}$ & $0.05 \pm 0.00 \mathrm{a}$ \\
\hline Sand & $84.13 \pm 0.94 \mathrm{a}$ & $83.24 \pm 0.73 a$ & $83.04 \pm 0.63 a$ & $83.00 \pm 0.70 \mathrm{a}$ \\
\hline Clay & $9.38 \pm 0.48 \mathrm{a}$ & $9.82 \pm 0.31 \mathrm{a}$ & $10.26 \pm 0.25 \mathrm{a}$ & $9.86 \pm 0.38 \mathrm{a}$ \\
\hline Silt & $6.49 \pm 0.62 \mathrm{a}$ & $6.66 \pm 0.42 \mathrm{a}$ & $6.43 \pm 0.038 \mathrm{a}$ & $7.14 \pm 0.49 \mathrm{a}$ \\
\hline $\mathrm{N}$ & $0.09 \pm 0.01 \mathrm{a}$ & $0.11 \pm 0.13 \mathrm{a}$ & $0.12 \pm 0.14 \mathrm{~b}$ & $0.13 \pm 0.18 b$ \\
\hline $\mathrm{P}$ & $26.38 \pm 2.64 \mathrm{a}$ & $27.66 \pm 2.64 \mathrm{a}$ & $19.60 \pm 2.28 b$ & $19.33 \pm 2.12 b$ \\
\hline $\mathrm{K}$ & $106.1 \pm 4.63 \mathrm{a}$ & $113.57 \pm 4.06 \mathrm{a}$ & $106.97 \pm 7.29 a$ & $120.28 \pm 7.28 \mathrm{a}$ \\
\hline $\mathrm{Ca}$ & $3.77 \pm 0.35 \mathrm{a}$ & $4.01 \pm 0.35 \mathrm{a}$ & $4.55 \pm 0.52 b$ & $4.75 \pm 0.42 b$ \\
\hline $\mathrm{Mg}$ & $0.93 \pm 0.10 \mathrm{a}$ & $1.08 \pm 0.10 \mathrm{a}$ & $0.90 \pm 0.08 \mathrm{a}$ & $0.95 \pm 0.09 \mathrm{a}$ \\
\hline $\mathrm{Na}$ & $0.04 \pm 0.00 \mathrm{a}$ & $0.03 \pm 0.00 \mathrm{a}$ & $0.04 \pm 0.00 \mathrm{a}$ & $0.04 \pm 0.00 \mathrm{a}$ \\
\hline $\mathrm{OM}$ & $3.46 \pm 0.35 \mathrm{a}$ & $4.15 \pm 0.34 \mathrm{a}$ & $4.26 \pm 0.04 a$ & $4.30 \pm 0.431 \mathrm{a}$ \\
\hline \multicolumn{5}{|l|}{ Microclimate } \\
\hline$T_{\mathrm{s}}$ & $27.92 \pm 0.87 \mathrm{a}$ & $26.60 \pm 1.00 \mathrm{a}$ & $31.67 \pm 0.45 b$ & $30.01 \pm 0.57 b$ \\
\hline$T_{\mathrm{sn}}$ & $33.37 \pm 0.79 \mathrm{a}$ & $27.77 \pm 0.87 b$ & $39.36 \pm 0.71 \mathrm{c}$ & $33.03 \pm 0.82 \mathrm{a}$ \\
\hline$T_{\mathrm{a}}$ & $23.17 \pm 0.21 \mathrm{a}$ & $22.55 \pm 0.47 \mathrm{a}$ & $25.17 \pm 0.55 b$ & $23.69 \pm 0.53 b$ \\
\hline $\mathrm{RH}_{\mathrm{a}}$ & $40.50 \pm 0.55 \mathrm{a}$ & $42.95 \pm 0.34 b$ & $38.03 \pm 0.64 \mathrm{c}$ & $39.92 \pm 0.54 \mathrm{a}$ \\
\hline
\end{tabular}

Different letters indicate significant differences $(p<0.001)$

CO canopy openness (\%), CC canopy coverage (100-CO\%), LAI leaf area index $\left(\mathrm{m}^{2} \mathrm{~m}^{-2}\right)$ (note that variable LAI provided by GLA software may be considered as Plant Area Index or Vegetation Area index, because of the inclusion of some trunks and tree branches in the captured image), (\%)Trans-Dir direct radiation transmitted (\%), (\%)Trans-Dif diffuse radiation transmitted (\%), (\%)Trans-Tot total radiation transmitted (\%), VWC soil volumetric water content (\%), $p H$ soil $\mathrm{pH}, E C$ electrical conductivity

$\left(\mathrm{dSm} \mathrm{m} \mathrm{m}^{-1}\right)$, sand, clay, and silt percentage of soil particles by size (\%), $N$ nitrogen content (\%), $P$ phosphorous content (mg $\left.\mathrm{kg}^{-1}\right), C a$ calcium content $\left(\mathrm{mg} \mathrm{kg}^{-1}\right), M g$ magnesium content

$\left(\mathrm{mg} \mathrm{kg}^{-1}\right), N a$ sodium content $\left(\mathrm{mg} \mathrm{kg}^{-1}\right), O M$ organic matter $(\%), T_{s}$ daily average soil temperature $\left({ }^{\circ} \mathrm{C}\right), T_{s n}$ soil temperature $\left({ }^{\circ} \mathrm{C}\right)$ at noon $(12-5 \mathrm{pm}), T_{a}$ average air temperature $\left({ }^{\circ} \mathrm{C}\right)$ at soil surface level, $R H_{a}$ average air relative humidity at soil surface level (\%)

comparing Shr-P/Shr-F treatments, though less clearly when comparing Shr-P/Shr-R. A change in the interaction sign was observed in relation to the seedling size, with a positive effect on the RGR for size 1 seedlings, a negative effect on size 2 seedlings and a positive effect on size 3 seedlings.

\section{Discussion}

The results of this study show simultaneous positive and negative interactions between $P$. pinaster seedlings and $C$. ladanifer shrubs, which is consistent with previous findings (Gómez-Aparicio et al. 2005; Holmgren et al. 1997; Holzalpfel and Mahall 1999). The relative growth rate varied significantly in relation to seedling size and was higher for larger seedlings irrespective of shrub environment. This suggests that seedling social status and size prior to shrub removal may be important factors in post-removal growth (Casquet et al. 2010). Shrub removal treatment had no significant effect per se on the relative growth rate except in the case of size 2 seedlings under open canopy, which showed the highest competitive-response ability. 
Table 4 Net balance of the shrub-seedling interaction calculated with the relative neighbour effect index (RNE) for Pinus pinaster seedlings of different sizes, under two types of canopy cover

\begin{tabular}{|c|c|c|c|c|}
\hline \multirow[t]{2}{*}{ Canopy } & \multirow{2}{*}{$\begin{array}{l}\text { Size } \\
\text { Shrub }\end{array}$} & \multicolumn{3}{|l|}{ RNE } \\
\hline & & 1 & 2 & 3 \\
\hline \multirow[t]{2}{*}{ Open } & Shr-P/Shr-R & -0.39 & -0.81 & -0.44 \\
\hline & Shr-P/Shr-F & -0.29 & -0.52 & -0.80 \\
\hline \multirow[t]{2}{*}{ Closed } & Shr-P/Shr-R & 0.27 & -0.09 & 0.27 \\
\hline & Shr-P/Shr-F & 0.08 & -0.09 & 0.57 \\
\hline
\end{tabular}

Negative values indicate competition, while positive values indicate facilitation. RGR was the performance variable used to calculate RNE

Shr-P/Shr-R net balance comparing seedlings growing in the presence (P) of shrub and seedlings with shrub removed (R), Shr-P/Shr-F net balance comparing seedlings growing in the presence $(\mathrm{P})$ of shrub and seedlings growing free $(\mathrm{F})$ of shrub

With the other treatments, a delayed effect on RGR, a wide range of phenotypic seedling plasticity, below-ground interactions or the need for a longer observation period cannot be ruled out, because the growth response was observed soon after treatment. Previous studies indicate a low RGR response and little or no significant shrub effect on this performance estimator in the regeneration of woody species (Gómez-Aparicio et al. 2005; Letourneau et al. 2004), pointing to the need for different seedling performance estimators in the evaluation of net plant-plant interactions (Maestre et al. 2006). The shrub-removal treatment itself might have influenced the seedling response. Recently Zhao et al. (2009) observed that the average annual increment in volume for the loblolly pine varied with the type of vegetation control treatment applied for site preparation.

The hypothesis that microclimatic and soil conditions would be affected by overstorey and understorey vegetation was confirmed. Microenvironmental conditions varied in relation to both canopy cover and shrub microsite, while soil conditions only varied in relation to canopy cover. The hypothesis that the strength of the interaction would increase with increasing seedling size was confirmed by the RNE index. The hypothesis of a shift from positive to negative interaction as the seedling size increases can be partially accepted, because we did not observe this pattern as a generalized response in both canopy types. The hypothesis of a stronger interaction under open canopy was confirmed, but the hypothesis of a positive interaction under open canopy can be ruled out for the performance estimator used. In spite of the generality of the stress-facilitation relationship (Bertness and Callaway 1994), species differ in their physiological and ecological optima. Stress is therefore relative to the particular species (Lortie et al. 2004; Liancourt et al. 2005), and may be relative to plant-specific traits (e.g., size or life stage) and resource availability. The plant performance estimator used, the experimental approach followed, and other stress factors not considered may have had a strong influence on both the net outcome of $P$. pinaster seedling-shrub interactions and the effect of the target abiotic stress on such outcomes (Maestre et al. 2006).

Shifts in the net interaction between shrubs and seedlings of different sizes under closed canopy and between canopy types could be interpreted within the model proposed by Holmgren et al. (1997). It describes the interchange between competition and facilitation on the basis of the prediction that plants cannot simultaneously adapt to shade and drought tolerance (Smith and Huston 1989). Another, more general application formulated by Liancourt et al. (2005) states that a facilitative outcome appears to be a function (trade-off) of a species having both a low tolerance to a particular stress (for example low light in shade intolerant species) and strong competitiveresponse ability. $P$. pinaster is a high-light demanding species (Awada et al. 2003), and has been classified as a drought-avoiding species with sensitive stomata (Picon et al. 1996). It is an early successional species that invades sites after disturbance and can grow quickly, competing with other plant forms (Richardson 1998). Open canopy creates what is likely to be the optimum light conditions for $P$. pinaster. If the abiotic conditions are not particularly harsh for that species (higher $\mathrm{N}$ and $\mathrm{Ca}$ content in the soil, lower soil temperature at noon and higher relative air humidity in shrub shade), competition may be expected (Liancourt et al. 2005). On the contrary, seedlings established under closed canopy may present high competitive ability due to higher availability of resources (higher phosphorus and VWC content in the soil under closed canopy), but low tolerance to abiotic conditions (e.g., shade), and may then be facilitated by shrubs. Since the outcome was found to vary with the seedling size, we are led into a new line of reasoning. A negative response after removal of the benefactor (Fig. 3) would indicate facilitation (Callaway 1995), as seen in size 1 and size 3 seedlings under closed canopy (Table 4). Facilitation may have been driven by changes in nutrient availability, which is known to occur with variations in soil moisture (Liancourt et al. 2005) and is more likely to affect growth (Goldberg and Novoplansky 1997). However, nutrient concentration in the soil did not vary significantly between shrub-shaded and shrub-free microsites. The low effect of shrub-treatment on seedling RGR may be due to energetic expenditure under adverse conditions, which implies a lower RGR but higher survival (Grime 1979), especially for small seedlings. So, we argue that for small seedlings, which are less stresstolerant due to their size, moisture limitation may be more important than nutrient and light limitations. Consequently, an improvement of moisture, likely connected to the amelioration of soil temperature and relative air humidity from shrub shade, would exceed the increased demand for 
moisture caused by light deterioration, resulting in a positive interaction (Holmgren et al. 1997). Mid-size seedlings may be more competitive because they have greater access to resources, due to a deeper root system or higher root density (Kramer and Kozlowski 1979); so light limitation may outweigh moisture or nutrient limitations, resulting in a negative interaction. We cannot discard the possibility that the positive RGR of size 3 seedlings under closed canopy may have arisen as an adaptation to competition for light and space. The corresponding increase in allocation to shoot growth in response to neighbour shade enables a seedling to overtop neighbouring shrubs (Bloom et al. 1985). This hypothesis is reinforced by the significant and positive relationship observed under closed canopy between $\ln V_{0}$ and $\operatorname{lnRGR}$ and, $\mathrm{CO}$ and radiation transmitted.

Finally, we cannot discard an indirect interaction resulting in facilitation under closed canopy (see Brooker et al. 2008), where cross effects between tree and shrub canopies may take place, and species may compete for different resources. Overstorey trees may have a negative effect on seedling RGR (supported by a negative correlation between initial seedling volume and overstorey density, LAI, soil $\mathrm{OM}$, and VWC) and shrub. Shrub may have a negative effect on seedlings, but if the benefit from suppression (adult trees on shrub) were higher than the direct negative effects, indirect facilitation may occur.

\section{Conclusions}

The results of this study show simultaneous positive and negative net interactions between established $P$. pinaster seedlings and $C$. ladanifer shrubs during the same growing period. The net effect and magnitude of seedling-shrub interaction varied with the life stage of $P$. pinaster and the overstorey structure. Social status and plant size appeared to be key factors in determining post-shrub treatment growth response. Differences in soil and microsite conditions between closed and open canopy were observed, which may control seedling growth. Regardless of canopy cover, the relative air humidity and soil temperature at noon varied between shrub-free and shrub-shaded microsites. These changes in microsite factors may determine $P$. pinaster secondary succession and regeneration structure. Further research is needed to explore the effects of shrub management on the natural regeneration of $P$. pinaster over several years and under different overstorey and climatic conditions. With a better understanding of the interaction between seedlings and shrubs, recommendations can be made for enhancing the natural regeneration of this species.

Acknowledgments We thank the editor and two anonymous referees for their valuable comments on the initial version of the manuscript. Andrea Blanch revised the English. M. Juverson Boosener revised the French. Dr. Gerardo Moreno kindly revised an initial draft of the manuscript. We are grateful to the Ministerio de Ciencia e Innovación for financial support for projects AGL20011780, AGL2004-07094-CO2-O2 and AGL2007-65795, and for grant BES-2005-7498. We thank Pedro Abati and La Sociedad de las Navas del Marqués, S.A. for assistance with stand selection, and the Spanish Climate Agency (AEMET) for climatic data. We also thank V. Pando for statistical support, and E. Escalante, S. Bogino, C. Herrero, P. Valbuena, A. Sanz, I. Ruano, A. de Lucas, M. Gómez, Y. Pallaviccini, and J. Díez for field assistance.

\section{References}

Awada T, Radoglou K, Fotelli MN, Constantinidou HIA (2003) Ecophysiology of seedlings of three Mediterranean pine species in contrasting light regimes. Tree Physiol 23:33-41

Beckage B, Kloeppel B, Yeakly JA, Taylor SF, Coleman D (2008) Differential effects of understory and overstory gaps on tree regeneration. J Torrey Bot Soc 135:1-11

Bertness B, Callaway R (1994) Positive interactions in communities. Trends Ecol Evol 5:191-193

Bloom AJ, Chapin FS III, Money HA (1985) Resource limitation in plants - an economic analogy. Annu Rev Ecol Syst 16:363392

Brooker RW, Maestre FT, Callaway RM, Lortie CL, Cavieres LA, Kunstler G, Liancourt P, Tielbörger K, Travis JMJ, Anthelme F, Armas C, Coll L, Corcket E, Delzon S, Forey E, Kikvidze Z, Olofsson J, Pugnaire F, Quiroz CL, Saccone P, Schiffers K, Seifan M, Touzard B, Michalet R (2008) Facilitation in plant communities: the past, the present, and the future. J Ecol 96:18-34

Callaway RM (1995) Positive interactions among plants. Bot Rev 61:306-349

Callaway RM, Walker LR (1997) Competition and facilitation: a synthetic approach to interactions in plant communities. Ecology 78:1958-1965

Callaway RM, Brooker RW, Choler P, Kikvidze Z, Lortie CJ, Michalet R, Paolani L, Pugnaire FI, Newingham B, Aschhoug ET, Armas C, Kikodze D, Cook BJ (2002) Positive interactions among alpine plants increase with stress. Nature 417:844-848

Casquet B, Montpied P, Dreyer E, Epron D, Collet C (2010) Response to canopy opening does not act as a filter to Fagus sylvatica and Acer sp. advance regeneration in a mixed temperate forest. Ann For Sci 67:105

Frazer GW, Canham CD, Lertzman KP (1999) Gap Light Analyzer (GLA), Version 2.0: Imaging software to extract canopy structure and gap light transmission indices from true-colour fisheye photographs, users manual and program documentation. Copyright (C) 1999. Simon Fraser University, Burnaby, British Columbia, and the Institute of Ecosystem Studies, Millbrook

Goldberg DE, Novoplansky A (1997) On the relative importance of competition in unproductive environments. J Ecol 85:409418

Gómez-Aparicio L, Valladares F, Zamora R, Quero JL (2005) Response of tree seedlings to the abiotic heterogeneity generated by nurse shrubs: an experimental approach at different scales. Ecography 28:757-768

Grime JP (1979) Plant strategies and vegetation processes. Wiley, Chichester

Hartgerink AP, Bazzaz FA (1984) Seedling-scale environment heterogeneity influences individual fitness and population structure. Ecology 65:198-206

Holmgren M, Scheffer M, Huston M (1997) The interplay of facilitation and competition in plant communities. Ecology 78:1966-1975 
Holzalpfel C, Mahall BE (1999) Bidirectional facilitation and interference between shrubs and annuals in the Mojave desert. Ecology 65:1747-1761

Kellman M, Kading M (1992) Facilitation of tree seedling establishment in a sand dune succession. J Veg Sci 3:679-688

Kitzberger T, Steinaker D, Veblen T (2000) Effects of climatic variability on facilitation of tree establishment in northern Patagonia. Ecology 81:1914-1924

Kramer PJ, Kozlowski TT (1979) Physiology of woody plants. Academic, New York, p 811

Letourneau FJ, Andenmatten E, Schlichter T (2004) Effect of climatic conditions and tree size on Austrocedrus chilensisshrub interactions in northern Patagonia. Forest Ecol Manag 191:29-38

Liancourt P, Callaway RM, Michalet R (2005) Stress tolerance and competitive-response ability determine the outcome of biotic interactions. Ecology 86(6):1611-1618

Lortie CJ, Brooker RW, Kikvidze Z, Callaway RM (2004) The value of stress and limitation in an imperfect world: a reply to Körner. J Veg Sci 15:577-580

Maestre FT, Valladares F, Reynolds JF (2006) The stress-gradient hypothesis does not fit all relationships between plant-plant interactions and abiotic stress: further insights from arid environments. J Ecol 94:17-22
Pecot SD, Mitchell RJ, Palik BJ, Moser EB, Hilers JK (2007) Competitive responses of seedlings and understory plants in longleaf pine woodlands: separating canopy influences above and below ground. Can J For Res 37:634-648

Picon C, Guehl JM, Ferhi A (1996) Leaf gas exchange and carbon isotope composition responses to drought in a drought-avoiding (Pinus pinaster) and a drought-tolerant (Quercus petraea) species under present and elevated atmospheric $\mathrm{CO}_{2}$ concentrations. Plant Cell Environ 19:183-190

Pugnaire FI, Haase P, Puigdefabregas M, Cueto M, Clark SC, Incoll LD (1996) Facilitation and succession under the canopy of a leguminous shrub, Retama sphaerocarpa, in a semiarid environment in southeast Spain. Oikos 76:455-464

Richardson DM (1998) Ecology and biogeography of Pinus. Cambridge University Press, Cambridge, p 527

Smith TM, Huston MA (1989) A theory of the spatial and temporal dynamics of plant communities. Vegetatio 83:49-69

Tielbörger K, Kadmon R (2000) Temporal environmental variation tips the balance between facilitation and interference in desert plants. Ecology 81:1544-1553

Zhao D, Kane M, Borders BE, Harrison M, Rheney JW (2009) Site preparation and competing vegetation control affect loblolly pine long-term productivity in the southern Piedmont/Upper Coastal Plain of the United States. Ann For Sci 66:705 